Таким чином, студенти виконали подвійне завдання: не лише ознайомилися з новою темою «Технологія тренінгу», а й, використовуючи метод «ажурна пилка», навчилися працювати в різних групах.

Із метою закріплення вивченого матеріалу на наступних практичних заняттях викладачем для студентів були запропоновані тренінги партнерського спілкування, які викликали в них неабиякий інтерес.

Отже, у процесі вивчення дисципліни «Інтерактивні технології навчання музичного мистецтва» студенти ознайомилися 3 інтерактивними технологіями навчання музичного мистецтва, окреслили особливості підготовки до занять, а також, що суттєво, визначили їх переваги та недоліки. Крім того, вони мали можливість закріпити отримані знання та навички на практиці, зокрема долучилися до підготовки презентацій 3 окремих тем професійних дисциплін, як-от: «Особливості виконавського стилю», «Історичні етапи розвитку музичного виконавства», «Джаз і сучасна музика», «Інструментознавство», «Методика викладання фахових дисциплін» та ін.

Висновки. Підсумовуючи викладене в статті, зауважимо, що використання студентами магістратури інтерактивних методів навчання у вивченні фахових дисциплін сприяє досконалому засвоєнню навчального матеріалу. При цьому практичні заняття, що базуються на інтерактивних методиках, формують комунікативні здібності майбутніх фахівців-музикантів, їх здатність до активної взаємодії з учасниками освітнього процесу, мотивують до застосування сучасних методів викладання дисциплін.
Подальші наші дослідження плануємо спрямувати на вивчення критеріїв модульно-рейтингового оцінювання знань студентів на заняттях за методикою інтерактивного навчання, що покликані стимулювати їх навчальну діяльність, викликати зацікавленість у вивченні дисциплін.

\section{СПИСОК ВИКОРИСТАНОЇ ЛІТЕРАТУРИ}

1. Ільченко О. О. Методологічні проблеми професійної музичної освіти : монографія / О. О. Ільченко, Я. В. Сверлюк. - Рівне : Перспектива, 2004. - 200 с.

2. Козлова Г. Компетентнісний підхід до навчання студентів і викладачів / Г. Козлова, Т. Кублікова // Вища школа. - 2011. - № 4 - С. 83-93.

3. Лісовий В. А. Магістерський рівень вищої освіти як основа професійного розвитку майбутніх фахівців музичного мистецтва / В. А. Лісовий // Мистецтво та освіта. - 2018. - № 1 (87). - С. 6-9.

4. Падалка Г. М. Педагогіка мистецтва: теорія і методика викладання фахових дисциплін : монографія / Г. М. Падалка. - К. : Освіта України, 2008. - 274 с.

5. П'ятакова Г. П. Інтерактивні методики та специфіка їх застосування у вищій школі : методичний посібник / Г. П. П'яткова, О. Л. Глотов. - Тернопіль : Studia metodologica, 2002. - $20 \mathrm{c}$.

6. П'яткова Г. П. Технологія інтерактивного навчання у вищій школі : навчально-методичний посібник / Г. П. П'яткова. - Львів : Видавничий центр ЛНУ імені І. Франка, 2008. - 120 с.

Дата надходження до редакиї: 10.12.2019 р.

Богдан СТОЛЯРЧУК, професор, завідувач кафедри музичного фольклору Iнституту мистеитв

Рівненського державного гуманітарного університету, заслужений діяч мистеитв Украӥни

\title{
ІНСТРУМЕНТАЛЬНИЙ АНСАМБЛЬ ТРАДИЦІЙНОЇ НАРОДНОЇ МУЗИКИ «ХУТІРСЬКІ МУЗИКИ» ТА ЙОГО РОЛЬ У ВИХОВАННІ МАЙБУТНІХ КЕРІВНИКІВ ФОЛЬКЛОРНИХ КОЛЕКТИВІВ
}

У статті представлено маловідомі сторінки щодо створення, становлення та розвитку інструментального ансамблю традииійної народної музики «Хутірські музики». Розкрито його роль у підготовиі майбутніх організаторів $і$ керівників ансамблів троїстих музик для закладів освіти і культури.

Ключові слова: ансамбль «Хутірські музики», фольклорист, басоля, ичимбали
В статье рассмотрень малоизвестные страницьь создания, становления и развития инструментального ансамбля традиционной народной музыки «Хуторские музыки». Раскрыта его роль в подготовке будущих организаторов и руководителей ансамблей тройственных музык для учреждений образования и культуры.

Ключевые слова: ансамбль «Хуторские музыки», фольклорист, басоль, ичимбальл. 
The article deals with the pages of creation and development of the instrumental group «Khutirs 'ki muzyky» and its role in the preparation of future organizers and leaders of "trinity music» ensembles in educational and cultural institutions.

At the Department of Musical Folklore Ukrainian traditional music specialists are prepare. They are trained their numbers in high school walls. Because it promotes the spiritual treasures of the Carpathians, the Bukovina, the Polissya, the Volyn. In its program are processing of folk songs for panpipe, cymbalo, violin, author's works.

From there, from the depths, the group takes more and more melodic treasures which are included in the program of the group. So the young people, in a figurative way, meet around the song. And if a student who is in love with a song is still educated in a profile higher education institution, then his life fortune prefers him to realize his artistic plans in an art group. Many true treasures have been accumulated by our ancestors. Especially in the countryside, they created, transmitted songs, music from generation to generation. Now this work is performed by the "Khutirs'ki muzyky».

The group "Khtirs'ki muzyky» is now doing a double thing: on the one hand - finds themselves in art, on the other hand-returns from oblivion or half oblivion what has already been created but it gradually fades away from the influx of artificial, secondary in our national art.

The group advocates preservation and popularization offolk instrumental music of the Western region of Ukraine (the Carpathians, the Bukovina, the Polesie, the Volyn).

The best dance music (polka,krakowiak) flicks printed in the book "Playing instrumental ensemble folk music «Khtirs'ki muzyky».

Key words: ensemble "Khutirs'ki muzyky», folklorist, basol, cymbals.

Постановка проблеми. Сьогодні, коли «зовнішній світ» переживає неабиякий інформаційний вибух, коли прийнято говорити про нову інформаційну цивілізацію, ми знову і знову звертаємося до традиційного мистецтва як до способу пізнання і самопізнання, способу отримання цілісного уявлення про світ та місце людини в цьому світі.

Музичний фольклор Полісся завжди привертав увагу дослідників, фольклористів, етномузикантів, а також широке коло залюблених у народну культуру особистостей. Рівненське Полісся як регіон, де й донині збережено архаїчні прадавні зразки народно-пісенної культури, - яскраве цьому підтвердження. Саме ця невелика територія ось уже впродовж кількох століть не лише притягує фахівців-дослідників своєю неповторністю, а й дивує архаїчними реліктовими знахідками звичаєвості, обрядовості та високою пісенною культурою, що прийшла до нас iз давніх-давен і сьогодні, на початку XXI століття, продовжує зачаровувати. Яскравим проявом цього $\epsilon$ і студентський ансамбль «Хутірські музики» Інституту мистецтв Рівненського державного гуманітарного університету (далі - РДГУ).

Означена стаття покликана представити широкому загалу не лише історію створення, становлення та розвитку колективу, а і його спробу виховати майбутніх музикантів - керівників музичних колективів.

Аналіз наукових досліджень i публікацій. У мистецькому житті Рівненщини ансамбль «Хутірські музики» - це приклад неабиякої майстерності як студентів, так і викладачів.
Свідченням цього є схвальні відгуки фахівців. Так, I. Кидрук у своїй статті «Хутірські музики» зазначає, що «учасники колективу не лише гуртуються навколо пісні, вони живуть нею» [4, с. 4]. О. Савчук у нарисі «Ювілей. Перша п’ятирічка віртуозів» наголошує: «Цей колектив - базовий, адже тут студенти проходять практику й одночасно готуються до здачі державного іспиту з ансамблем, а отже, рівень їх підготовки має бути високим. Підтвердження цьому - щорічний звіт колективу» [7]. С. Доленко зі свого боку в статті «Новини культури. «Хутірська музика» завойовує світ» зауважує, що «колектив «Хутірські музики», створений свого часу на кафедрі музичного фольклору, швидко знайшов свого слухача та шанувальника, і не лише в нашому краї, адже пропагує духовні скарби Волині й Полісся, Буковини та Карпат» [2].

Мета статті - охарактеризувати питання створення, становлення та розвитку інструментального ансамблю традиційної народної музики «Хутірські музики»; окреслити напрями діяльності колективу, спрямовані на розширення можливостей збору і запису традиційної поліської музичної спадщини, а також іiі включення до репертуару сучасних інструментальних ансамблів.

Виклад основного матеріалу. Інструментальний ансамбль традиційної народної музики «Хутірські музики» було створено у 1999 році Михайлом Хаєм, доктором мистецтвознавства, професором кафедри фольклористики Національної музичної академії України імені П. І. Чайковського; Богданом Яремком, кандидатом мистецтвознавства, професором кафедри музичного фольклору Інституту мистецтв Рівненського державного гуманітарного університету, а також Богданом Столярчуком, заслуженим діячем мистецтв України, професором кафедри музичного фольклору, а нині - іiі завідувачем та керівником ансамблю «Хутірські музики».

Робота на кафедрі музичного фольклору пов'язала автора статті із керівництвом інструментальної групи фольклорного ансамблю «Горина», засновником і керівником якого був відомий на Рівненщині та в Україні фольклорист, майстер своєї справи Василь Павлюк. Саме учасники «Горини» під його керівництвом долучилися до відродження пісенних традицій Рівненського Полісся.

Проте, як відомо, на Поліссі, крім співу, були популярні ще й музи́ки, які часто супроводжували веселі пісенні дійства. Тобто, склалася традиція ансамблевої гри на народних інструментах. Таким ансамблем у народній практиці була троїста музи́ка. Її типовий склад: скрипка, басоля, бубон або дві скрипки, гармошка, великий барабан (кількість музикантів залежала від регіону).

Свого часу кафедра музичного фольклору РДГУ поповнилася новими музикантами-інструменталістами з різних регіонів Західної України, а як наслідок - виникла потреба у створені самостійного колективу. Основним інструментом в ансамблі стала скрипка, якій притаманні особливі художньо-виражальні й технічні можливості. Першими скрипалями стали студенти-випускники музичних училищ Вікторія Ярмола (Рівненське музичне училище) та Роман Нярба (Чернівецьке училище культури). Саме вони були основою колективу, хоча й не мали на той час достатніх навичок гри традиційної музики. Тому перед викладачами постало нелегке завдання - навчити студентів переймати манеру гри в гуртовому музикуванні 
певного регіону, що вимагало неабияких фізичних зусиль, систематичних індивідуальних занять та постійних ансамблевих репетицій.

Поліську традицію досліджувала Вікторія Ярмола, яка пізніше на цьому матеріалові захистила кандидатську дисертацію. До репертуару колективу увійшли такі твори, як «А дівчина по базарчику ходила», «А ця полька дрібно скаче», «Поліська полька» та ін.

Буковинську скрипкову традицію, яка має зовсім іншу манеру виконання (соло в ансамблі, складні пасажі, кантиленні епізоди, різноманітні фігурації) презентував Роман Нярба. Серед таких творів варто виокремити «Ранок на Буковині», полька «Нярбівка» та ін.

Польку із села Пороги Богородчанського району Івано-Франківської області записав і транскрибував Василь Квич. Він виконував їі так, як це робили сільські музики його рідного регіону. Ця полька пройшла через його душу і серце. Будучи ще студентом кафедри музичного фольклору, він, виконавши іiі, став лауреатом III Міжнародного фестивалю традиційної народної культури «Покуть - 2000» (Харків), конкурсу «Нові імена» (Рівне, 2002), молодіжного фестивалю сучасної пісні «Золотий тік» (Галич, 2002). Це дало йому можливість грати сольні твори у супроводі ансамблю «Хутірські музики».

Важливе місце в ансамблі займала й сопілка один із найдавніших духових музичних інструментів. Вона не лише надзвичайно проста за будовою і доступна за технікою гри, а ще й має особливі музично-виразні можливості, до того ж портативна, адже iii легко можна носили за поясом, халявою чи просто за пазухою. В ансамблі сопілка використовувалася як сольний інструмент свистково або у поєднанні «сопілка - бубон», «сопілка - бугай».

У 2000 році на кафедру музичного фольклору вступив випускник Дрогобицького музичного училища, прекрасний сопілкар Тарас Горін. Із його приходом до інструментального ансамблю почалася робота над авторськими творами для сопілки та ансамблю. Зокрема, була виконана його власна «Фантазія на українські теми», а також «Традиція на теми гуцульських народних мелодій» Василя Попадюка та «Гуцульська фантазія» Михайла Тимофієва. Тарас Горін добре володів інструментом, тому йому під силу був не лише технічний матеріал, а й кантилена. Завдяки своїй наполегливій праці він стає лауреатом і дипломантом мистецьких молодіжних конкурсів та фестивалів, зокрема «Таланти рідного краю», «Нові імена», «3 народного джерела», «Древлянські джерела». Митець здобував перемоги під пильним керівництвом професора Богдана Яремка. Ще одним представником школи Богдана Івановича $\epsilon$ Олександр Рибалко, який із часом став невід'ємною частиною колективу кафедри музичного фольклору РДГУ.

Неабиякої музичної окраси набув колектив із приходом у 2000 році студента-цимбаліста Степана Ткача, випускника Калуського училища культури. Високопрофесійний музикант відразу привернув до себе увагу. Майстер-цимбаліст у нашому краї відкрив нове дихання троїстої музики. Так, у репертуарі «Хутірських музик» з'являються твори Дмитра Попічука для сопілки («Гуцулка»), Іллі Міського для цимбалів та ансамблю («Українська п’єса»), Василя Попадюка для цимбалів («Фантазія на гуцульські теми»).

В Україні цимбали вперше згадуються у 80-х роках XVII ст., зокрема А. Рігельман, пишучи про українських музик, згадує і цимбалістів. У другій половині XX ст. у побуті українського села цимбали стають надзвичайно поширеним музичним інструментом, який зазвичай виготовлявся народними майстрами Івано-Франківщини. На Західній Україні (Львівщина, Тернопільщина, Івано-Франківщина, Буковина) цимбали входили до складу троїстої музики. Ще Микола Лисенко, описуючи українські народні інструменти кінця XIX ст., зауважував, що народні пісні неодмінно пов'язані з цимбалами у співзвуччі зі скрипками. Таке поєднання було найулюбленішою композицією інструментів нашого народу. Широко відомою є троїста музика, що складалася зі скрипки, баса та цимбал, які нерідко грали на весіллях та вечорницях (здебільшого на Галичині, Покутті, Коломиївщині).

Сьогодні викладачем цимбалів Рівненського музичного училища є Степан Ткач. Видатний майстер виховав цілу плеяду музикантів, які нині працюють у музичних школах нашої області або навчаються в престижних музичних закладах України. Так, випускниця майстра, Марія Новицька, навчається на кафедрі музичного фольклору та $є$ активною учасницею інструментального ансамблю «Хутірські музики», продовжує традиції свого вчителя та має у своєму репертуарі твір Василя Попадюка «Фантазія на гуцульські теми».

Важлива роль в ансамблі належить басу, який є ключовим інструментом троїстих музик. Проте працівники відділу фольклору Рівненського обласного науково-методичного центру народної творчості та культурно-освітньої роботи разом із викладачами Рівненського державного інституту культури (тепер - Інститут мистецтв РДГУ) відшукали такий давній поліський музичний інструмент, як басоля - камерно-смичковий бас - із чотирма жиленими струнами довжиною 1500 мм. У 80-х роках ХХ ст. іiї було віднайдено в м. Дубровиці Рівненської області завдяки знавцеві народної творчості, керівникові народної аматорської народної хорової ланки с. Кураня Петру Степанюку. Виготовив інструмент місцевий майстер Михайло Ракович. Такі музичні інструменти здебільшого побутували на території Білорусі та в деяких західних областях України, зокрема й на Рівненщині. Свідченням цього є давні світлини старожилів Дубровиці, де трапляється ії зображення. Сьогодні означена басоля зберігається в експозиції Рівненського обласного краєзнавчого музею.

Найбільш поширеними є саморобні басолі на три або чотири струни, власноруч зроблені басолістами. У ансамблі «Хутірські музики» використовується віолончель фабричного виробництва, на якій троїсті музики грають щипком, саморобним коротким смичком та пліткою. Завдяки цьому їм було властиве своєрідне звучання: національний колорит, багатство мелізматики і тембрових забарвлень, оригінальні прийоми гри та звуковидобування.

Крім того, в ансамблі басовий фундамент забезпечує чотириструнний контрабас, партія якого готується октавою, вищою від дійсного звучання. Звернувшись до історії музикування та етноінструментування, можемо зауважити, що бас (басоля, басетля, контрабас) був традиційним музичним інструментом у складі троїстих музик. Це засвідчують також історіографічні джерела й трансформації старожилів Волинського Полісся: коли на території нашого краю вигравав бас, то вважалося, що троїста музика «витинає по-місцевому», «тутешньому» [8, с. 1$]$.

Поява баса, басолі й басетлі в народному побуті спостерігалася набагато пізніше, ніж скрипки. 
У народному музикуванні «смичковий бас» використовувався значно менше ніж скрипка, оскільки він був лише ансамблевим інструментом.

В ансамблі також використовується великий барабан - це циліндр, обтягнутий з обох боків шкірою, зверху якого закріплено маленьку тарілочку. Грають на ньому спеціальною дерев'яною палицею 3 м'якою котушкою на кінці.

Ансамбль народної музики «Хутірські музики» на кафедрі музичного фольклору РДГУ функціонує вже понад двадцять років. Його основна мета - відтворення інструментальної музики Гуцульщини, Поділля, Полісся, Волині та Буковини. Склад інструментів ансамблю частково змінюється, залежно від того, $з$ якого регіону відтворюється записана й розшифрована студентами музика, наприклад: бубон, скрипка, сопілка, цимбали, контрабас; скрипка, цимбали, бубон; скрипка, басоля, дві скрипки. Студентам в ансамблі під час навчального процесу проходять практику традиційного музикування, роблять інструментування й відтворюють музику, записану в тому регіоні, звідки вони родом.

Як уже зазначалося вище, у репертуарі колективу - традиційна народна інструментальна музика Карпат, Буковини, Полісся, Волині; обробки народних мелодій для сопілки, цимбал, скрипки; авторські твори Василя Попадюка, Дмитра Попічука, Петра Терпелюка; інструментування Михайла Тимофієва, Юрія Полєвого, Богдана Столярчука та багатьох інших українських композиторів. Із 2001 року ансамбль провадить активну культурно-мистецьку діяльність та $є$ володарем значної кількості відзнак і нагород. Зокрема, «Хутірські музики» - неодноразові переможці конкурсу молодих виконавців української народної музики «3 народного джерела» (дипломанти 2001 та 2004 років; лауреати III премії 2002 та II премії 2003 років), дипломанти молодіжного фестивалю «Нові імена» (Рівне, 2004), лауреати V Bceукраїнського фестивалю-конкурсу молодих виконавців української народної музики, присвяченого 125-річчю від дня народження Климента Квітки (III премії у 2005 та I премії - у 2006 роках), дипломанти V Міжнародного молодіжного фестивалю традиційної культури «Древлянські джерела» (Рівне, 2005 р.).

Крім того, колектив ансамблю отримав подяки за активну участь у культурно-мистецьких заходах (із нагоди 16-річчя від Дня Незалежності України та Дня міста Рівного) та в VII Міжнародному музичному фестивалі традиційної народної культури «Древлянські джерела» (Рівне, 2007).

Музиканти нагороджені грамотою за перше місце в III Обласному огляді-конкурсі художньої самодіяльності працівників освіти і науки (Рівне, 2005) і дипломом за оригінальне художнє самовираження й активну участь у заходах IX Міжнародного фестивалю традиційної народної культури «Древлянські джерела» (Рівне, 2010).

Ансамбль «Хутірські музики» і до сьогодні не втрачає своїх виконавських навичок та $є$ неодмінним учасником творчих звітів кафедри, університетських та міських виступів і концертів.

Деякі випускники ансамблю створили власні колективи, продовжуючи традицію, започатковану на кафедрі музичного фольклору. Так, Степан Ткач - керівник ансамблю Оржівської дитячої музичної школи; Ольга Олексюк - керівник ансамблю народної музики Люблінської школи мистецтв та учасниця фольклорного ансамблю «Родина» (с. Білин Ковельського району Волинської області); Ольга Остапова - керівник ансамблю народної музики «Перепілонька» Рівненської дитячої музичної школи № 2; Олександра Артюхова - керівник фольклорного ансамблю «Кобза» Тульчинського училища культури Вінницької області. Крім того, колишні випускники є учасниками різноманітних інструментальних колективів, значна кількість із них - лауреати та дипломанти престижних міжнародних і всеукраїнських конкурсів виконавців на українських народних інструментах (імені Гната Хоткевича (Харків), «Золотий ріг» (Галич), «Таланти рідного краю» (Рівне), «Народні музики Поділля» (Немирів) та ін.).

Отже, підсумовуючи вищезазначене, зауважимо, що професійна робота на кафедрі музичного фольклору - це результат фахової підготовки майбутніх керівників колективів та окремих виконавців, які за період свого навчання у закладі набувають навичок спеціальної музичної підготовки в оволодінні інструмента, на якому грають; опановують запис та транскрибування творів традиційної музики, з якою працюють, основи диригування та вивчення літератури народів світу, що дає можливість майбутньому керівнику фольклорного колективу готувати високопрофесійних фахівців.

Висновок. Ансамбль «Хутірські музики» робить нині подвійну корисну справу: з одного боку, впевнено крокує мистецьким шляхом, виконує педагогічну та виховну функції, адже його учасники набувають тут досвіду й згодом, закінчивши навчання, самі стають керівниками нових колективів, а 3 іншого повертає із забуття чи напівзабуття те, що вже було колись створено, але поступово відійшло в небуття внаслідок напливу «штучного, вторинного, крикливого» в нашому національному мистецтві.

Хочеться вірити, що відродження народної музики з їі традиційними обрядами у виконанні народних інструментальних ансамблів займе вагоме місце в національній культурі нашого народу.

\section{СПИСОК ВИКОРИСТАНОЇ ЛІТЕРАТУРИ}

1. Гуменюк А. Українські народні музичні інструменти / А. Гуменюк. - Київ, 1967. - 244 с. : іл.

2. Доленко С. Новини культури. «Хутірська музика» завойовує світ / С. Доленко // Нова Волинь : незалежна громадсько-політична газета. - 2004. 2 грудня - С. 4.

3. Іванов А. Оркестр українських народних інструментів / А. Іванов. - Київ, 1981. - 110 с.

4. Кидрук I. «Хутірські музики» / I. Кидрук // Вiсті Рівненщини : газета. - 2004. - 24 листопада. - С. 4.

5. Лисенко М. Народні музичні інструменти на Україні / М. Лисенко ; за ред. М. Щоголь. - К. : Мистецтво, 1955. - 62 с.

6. Пшеничний Д. Інструментування для оркестру народних інструментів / Д. Пшеничний. - К. : Музична Україна, 1985. - 69 с.

7. Савчук О. Ювілей. Перша п'ятирічка віртуозів / О. Савчук // 7 днів : газета. - 2004. - 3 грудня. - С. 6.

8. Столярчук Б. Інструментування для народних ансамблів / Б. Столярчук. - Рівне, 2001.

9. Украинские народные наигрыши / сост. В. Гуцал. - М. : Музыка, 1986.

Дата надходження до редакиії: 18.12.2019 p. 